\title{
TOXIN-ANTITOXIN SYSTEMS AND THEIR ROLE IN MAINTAINING THE PATHOGENIC POTENTIAL OF CAUSATIVE AGENTS OF SAPRONOSES
}

Boris G. Andryukov ${ }^{1,2,3^{*}}$, Larisa M. Somova ${ }^{1}$, Nellie F. Timchenko ${ }^{1}$, Marina P. Bynina ${ }^{1}$, Irina N. Lyapun ${ }^{1,3}$

${ }^{1}$ Somov Research Institute of Epidemiology and Microbiology, Vladivostok, 690087, Russia;

${ }^{2}$ Far Eastern Federal University, Vladivostok, 690950, Russia;

${ }^{3}$ Scientific Research Testing Institute of Military Medicine, Vladivostok, 690080, Russia

\begin{abstract}
In interepidemic periods, a sapronoses typically employs a variety of mechanisms for maintaining viability of its causative agent in terrestrial parasitic systems, associated with different adaptive strategies utilized by its populations to survive. Unlike spore-forming bacteria, causative agents of sapronoses use resistant cell forms, which is a viable but nonculturable (VBNC) state, and persistence. Implementation of these strategies is conditioned by effects of various stress factors of the habitat and is characterized by decreased metabolism, alteration of the morphology and physiology of bacterial cell, and cessation of its replication. It is important that the resistant forms of cells retain virulence and, as favorable conditions come, turn back into the active vegetative form again. The discovery of the genetic modules of bacterial toxinantitoxin systems in recent years has made it possible to identify a number of complicated regulatory molecular mechanisms responsible for maintaining the pathogenic potential of resistant forms of causative agents of natural-focus sapronoses in interepidemic periods.
\end{abstract}

Keywords: toxin-antitoxin systems, toxin-antitoxin genetic module, sapronoses, resistant (dormant) cell form of bacteria, viable but nonculturable (VBNC) cell, persistence.

*Author to whom correspondence should be addressed: Andryukov Boris Georg., DM, prof., leading researcher of the Laboratory of Molecular Epidemiology and Microbiology, G.P. Somov Research Institute of Epidemiology and Microbiology, professor of School of Biomedicine Far Eastern Federal University; e-mail: andrukov_bg@mail.ru; tel.+7(924)2304647. 


\section{Introduction}

The issue of survival of pathogenic microorganisms and the ways of their existence in the environment has become one of the most urgent problems in modern microbiology. The endemism of sapronoses (from Greek "sapros" = decaying; "sapron" - in ecology - a decaying organic substrate) is associated with the ability of their causative agents to survive in natural ecosystems $[1,2]$. The most important characteristics of causative agents of the sapronoses are The ability of the pathogens to grow and replicate in these substrata (i.e saprophytically) [2]. Thus these microorganisms are a distinctive type of infectious agent: they carry on dual ways of life: parasitic (pathogenic, at the temperature of a host organism) and saprophytic (in an abiotic substrate at ambient temperature) [1,2].

Ecological and epidemiological study of sapronoses is of not only medical, but also of general biological importance. Despite the rather long history of the study of sapronoses, the newly forming ideas about symbiotic relationships, parasitic systems, and adaptation strategies of their causative pathogens increasingly diverge from the classical epidemiological and biological concepts [3]. This is explained in part by the lack of both generally accepted terminology and a common view on ecological features of pathogens during their circulation in the natural environment and in human body $[2,4,5]$.

The paradigm of interepidemic periods includes two modes of existence of pathogens: active (circulation out of a terrestrial parasitic system, in soil or in a body of water) and passive (reservation in a resting, inactive state).

The existence of resistant (dormant) cell forms in non-spore-forming bacteria inhabiting soils and waterbodies, viable but nonculturable (VBNC) cells, as well as the phenomenon of persistence of bacteria in the organism in warm-blooded animals and humans, were discovered in the late $20^{\text {th }}$ century $[2,3,5]$.

The resistant cell forms with low metabolic and replication activity cannot be detected by traditional microbiological methods [6,7]. These forms are highly significant for a large and diverse group of causative agents of sapronoses, as they allow them to implement their biological properties: environmental plasticity, a variety of forms of resistance to external stressors, the acquisition of resistance to antibiotics and other antibacterial agents $[5,8]$.

The surge of scientific interest in resistant forms of infectious agents in recent years is associated with the increasing medical and epidemiological significance of the phenomenon of resistant cell forms, as well as with the invention and development of molecular cell biology methods and the discovery of genetic modules of toxin-antitoxin systems (TAS) [3]. This served as a basis for the development of fundamentally novel technologies to study the mechanisms responsible for maintaining the pathogenic potential of resistant cell forms of causative agents of 
natural-focus sapronoses in interepidemic periods [2, 5].

The boundary position of this unique and vast group of bacteria capable of both parasitic and saprophytic existence explains the insufficient knowledge of the strategies and ways for reservation of agents and maintaining their virulence [9]. It is possible that the disclosure of the mechanisms of involvement of TAS in the formation of resistant bacterial forms will become the missing link in the study of the general strategies utilized by pathogenic agents of natural-focus sapronoses to survive in humans, animals, and in the environment.

The goal of review: to show the importance of genetic modules of TAS in the emergence of resistant forms of bacterial cells and in maintaining the pathogenic potential of causative agents of sapronoses.

\section{Causative agents of sapronoses}

Sapronoses (from Greek sapros, meaning "putrid", and nosos, "disease") are diseases transmitted to humans from abiotic substrates of the environment (soil, water, decaying plants, animal feces, etc.) [1].

The most important feature of sapronoses is that bacteria, as causative agents, not only persist, but also actively reproduce on abiotic substrates (saprophytic phase), and, after getting in the body of a warm-blooded animal (or human), continue to replicate in it (parasitic phase). Possible sources of pathogens are animals, and this assumption gave reason to refer to this group of infections as saprozoonoses [2].

Causative agents of this group of infections include Legionella pneumophilia, Pseudomonas pseudomallei, Listeria monocytogenes, Vibrio cholerae, Erysipelothrix, Bacillus anthracis, Leptospira interrogens, Yersinia pseudotuberculosis, Yersinia enterocolitica, Vibrio cholerae spp. and other bacteria, whose main natural habitat are abiotic objects of the environment [5].

The pathogenic properties of causative agents of natural-focus sapronoses are based on the genetically determined pathogenicity factors (adhesins, invasins, enzymes, toxins, etc.), which have formed during their evolution to ensure existence in the environment and penetration into cells and tissues of organisms of the soil-dwelling, aquatic, and marine flora and fauna [5, 10]. These multipurpose pathogenicity factors, due to the complementary properties of their determinants, can affect the respective chemical targets, both in objects of the environment and in the organism of warm-blooded animals and humans [9].

The paradigm of natural foci of diseases has long been based on the postulate of continuous circulation of pathogens within a certain area. However, a thesis on the interepidenic (interepizootic) periods and the discrete pattern of pathogen's circulation (seasonal, annual, and perennial) as the regular features of natural foci has been formulated and substantiated in recent 
decades $[4,5,9]$. It became obvious that in terrestrial ecosystems, circulation of pathogenic agents of sapronoses (plague, pseudotuberculosis, leptospirosis, listeriosis, melioidosis, legionellosis, cholera, tularemia, and anthrax) is also limited in time and space [9].

For instance, discontinuities in the active circulation of Yersinia pestis can last for dozens of years $[5,9]$. The discrete pattern of circulation of sapronoses causative agents is expressed also in epidemic manifestations of cholera and other infections, whose natural foci are associated with aquatic and terrestrial systems [3,9].

Thus, the causative agents of typical sapronoses, inhabiting the environment, can exist and proliferate without any relations with warm-blooded organisms and acquire the epidemiological significance when the opportunity arises of their transfer from natural habitats to the organism of a warm-blooded animal (or human), where they continue replication. The availability of two environments contributes to their survival in the biosphere and determines their further evolution in this direction $[1-4,9]$.

As inhabitants of different ecosystems, the causative agents of sapronoses are continuously exposed to potentially dangerous adverse factors, which caused them to develop certain adaptation strategies of genetic self-regulation in the course of their evolution [2-4].

These strategies provide not only high ecological plasticity of saprophytic microorganisms, but also the possibility of survival of pathogens with a significant infectious potential under the effect of numerous environmental factors and in the human body. The hospital environment can also be a source of sapronoses infections: medical tools and equipment, transplants and biologic fluids, in which the pathogens remain for a long time in the form of biofilms, resistant cell forms, and spores. This provides the phased development of epidemic manifestations of hospitalacquired infections with a periodic dominance of multiresistant clones [11-13].

As is known, spore-forming pathogenic bacteria (clostridia and bacilli), after being exposed to a sharp reduction in nutrients in the habitat, can persist for decades in soils in the form of resting forms, spores, or cysts until favorable conditions for reproduction return. For instance, spores of Bacillus anthracis, the causative agent of anthrax, can germinate in soil under favorable conditions and complete the full vegetative cycle [7].

In the late $20^{\text {th }}$ century, the existence of resting ("dormant") resistant cell forms was first reported for non-spore-forming bacteria inhabiting soils and water bodies and found in organisms of warm-blooded animals and humans [14]. Subpopulations of these cell forms are characterized by reduced growth rates and metabolic activity, but, with the onset of optimal conditions for growth, they can quickly restore the pathogenic characteristics that they had previously $[6,7]$.

The evolutionary significance of maintaining such heterogeneity of population is similar to 
the genetic strategies of phenotype formation, determined by the genotype and environmental conditions, which increase the probability of survival of microorganisms in unstable environmental conditions, as well as under the effect of antibacterial agents [8].

The formation of resistant forms in causative agents of sapronoses is induced by a number of environmental stress factors (variations in the hydrothermal regime, shortage of nutrients, exposure to antibiotics, etc.) and exhibits a pronounced adaptive property $[1,6]$.

Causative agents of sapronoses, after transiting to a nonculturable state, become capable of long-term existence in the external environment, outside a warm-blooded organism. At the same time, inactive cells retain their pathogenic potential and, under favorable conditions, again transform into vegetative forms [7].

To date, resistant forms have been isolated from many bacteria, including causative agents of (plague, pseudotuberculosis, listeriosis, and other sapronoses) [8, 13]. The detection of these forms of causative agents of sapronoses in foci, soils and water bodies, was confirmed by the results of experimental studies on the induction of the reversible transition of Yersinia, Listeria, and Salmonella into the resting state $[2,4,9]$.

After the discovery of these adaptive phenomena, it was assumed that the mechanisms of reversible transition of bacteria into a resting state and the reverse transition to vegetative (active) forms have a complex genetic regulation and are induced by a combination of biotic and abiotic factors of the environment $[1,5,10]$.

Seasonal and climatic variations in expression of these factors can cause an adaptive rearrangement of microbial populations and induce the transition of vegetative forms, typical of the circulation phase of pathogens, into a resting state which provides their reservation in the interepidemic periods in natural foci, as well as cause exacerbation, recurrence, and chronization of the infection $[3,4,15,16]$.

To date, two well-defined resistant forms in non-spore-forming bacteria have been sufficiently characterized: a viable but nonculturable (VBNC) state and cell persistence.

\section{Resistant cell forms}

Culturability of microbes is one of the fundamental microbiological characteristics, and coordinated reproduction of all cellular components and structures, eventually leading to an increase in cell weight, is one of the main criteria for its viability. However, in the 20th century, anabiotic forms of existence that did not fully meet the viability criterion were described from microorganisms. These are persister cells and VBNC bacteria that have been combined under the common term "resting cell forms" [7, 17].

Persister cells. The effect of bacterial cell persistence was discovered in the middle of the 20th century. In the subsequent numerous works, the phenomenon of bacterial persistence has 
been comprehensively studied [1, 18-22]. In particular, it was found that persister cells usually make up only a small fraction of the bacterial population. In wild-type E. coli strains, their frequency in plankton cultures constitutes approximately one per million cells [15, 23]. However, in biofilms, which are complex multicellular bacterial communities highly resistant to antibiotics and are responsible for more than $80 \%$ of human infections, their frequency increases substantially: up to one per 100 bacteria [23].

The mechanism of formation of temporary antibiotic-resistance of persister cells is associated with the replicative and metabolic rest of bacteria being in a persistent state $[13,17]$. The mechanism of action of most antibiotics is aimed at suppressing the vital intracellular processes of metabolically active and growing cells, and, therefore, the effectiveness of these drugs depends on the physiological state of the cell. From this aspect, the phenomenon of persistence is considered as the emergence of spontaneous and temporarily antibiotic-resistant phenotypic cell variants in isogenic bacterial populations [13].

According to the latest definition, persister cells are considered as resting and irregular subpopulations existing in a growing culture that are resistant to several types of antibiotics, antiseptics, and disinfectants $[8,13,24]$. Their fundamental difference from antibiotic-resistant mutant bacteria is that persister cells do not divide, and their tolerant phenotype is retained only during the resting state period and, therefore, is not inherited [23, 25].

It could seem that the mechanism of phenotypic antibiotic-resistance of persister cells is associated exclusively with the state of metabolic and replicative rest. However, recent studies $[12,18,21,22]$ have shown the physiological heterogeneity of the fraction of persister cells in a population and the different degrees of resistance to various antibiotics [12]. The experimental selective inhibition of bacterial replication caused the antibiotic-resistance only when the inhibition was accompanied by an active cells' response to stress. Other researchers $[17,26]$ have shown that suppression of the metabolic activity of bacterial cells alone did not prevent mortality of $99 \%$ of the population from antibacterial agents.

Moreover, in the works of E. Maisonneuve et al. [19] and Van den Bergh et al. [27] it is reported that a phenotypic population of single persister cells is present in most bacterial cultures being in the stationary phase of growth and free of antibiotic and stress exposure. During their life cycle, vegetative (active) bacterial cells of populations can transform into a persistent phenotype and back, with the rate of such reversals depending on the growth phases and habitat conditions $[19,27]$.

Thus, a conclusion has been made that the induction of persister cells' formation is not associated solely with the effect of antibacterial agents, and the levels of bacterial persistence depend on a number of environmental factors and a genetically determined mechanism of 
regulation of their formation $[8,13,17]$. These cells protect the population from death caused by a sudden and massive antibiotic therapy, providing microorganisms with a competitive advantage in periodically changing environmental conditions $[13,17]$.

The presence of persister cells in a bacterial culture, including causative agents of sapronoses, is of increasing pathogenetic significance as an etiological factor of a group of chronic and nosocomial infections (suppurative-septic infections, pneumonia, intestinal infections, tetanus, gas gangrene, etc.) $[3,26]$.

Viable but nonculturable cells. The saprophytic phase of sapronoses causative agents in natural ecosystems often occurs in unfavorable conditions. An unstable hydrothermal regime, lack of nutrients, and other stress factors of the environment threaten the survival of the population, which causes bacterial cells to enter their resistant dormant states and acquire the ability to survive in aggressive environmental conditions by radically changing their physiological and morphological organization.

Unlike normal bacteria, viable but nonculturable (VBNC) cells lose their ability to be cultured on growth media and to form colonies, while retaining signs of viability (intact cell membranes, minimal metabolic activity, and ongoing gene expression) [7]. It has been established that the VBNC state is induced by various environmental stressors (such as starvation, hypoxia, variations in hydrothermal regime and $\mathrm{pH}$, salinity increase, antibacterial agents, and disinfectants) $[6,11]$.

Over the past decades, nonculturable forms have been found in more than 100 species of bacteria belonging to 40 genera, of which more than 50 species are pathogenic or opportunistic for humans and animals. These cell forms of bacteria have been referred to in the scientific literature under various alternative terms: nonculturable cells, conditionally viable environmental cells (CVEC), active but nonculturable cells (ABNC), and dormant cells [16].

The clinical significance of noncultirable forms has been confirmed by numerous studies [6]. Pathogenic bacteria from biomaterial, being in the VBNC state, do not inoculate the diagnostic growth media in laboratory and, therefore, cannot be identified as an etiological agent. A negative microbiological response can influence a decision on discontinuation of antibiotic therapy and, thus, subsequently cause recurrence of the infection. In a study by M.M. Lleo et al. [28] it was shown that in $14-27 \%$ of cases of infection the pathogens proved to be unidentified by traditional microbiological methods, and their presence could only be detected through PCR. The same method revealed the quantitative increase in sub-populations of nonculturable forms of bacterial cells in biofilms. This increases their importance in the pathogenesis of human bacterial infections and necessitates active research to understand the molecular mechanisms underlying the phenomenon of persistence and its regulation [29]. 
To date, there is ample evidence that VBNC, like persistence, is an effective cellular strategy for bacteria to survive adverse growth conditions. Over the decades of studies of these resistant (dormant) forms, extensive data have been collected on the regulatory, morphological, and functional similarity of the persistence and VBNC state phenomena, and this resemblance has been discussed in detail in the literature [30].

Based on the similarity of conditions of emergence, morphological features, and molecular genetic mechanisms of these resistant forms, some authors put the equality sign between them [30]. However, most researchers point also to the differences that have been repeatedly confirmed in experiments. The major difference of VBNC is their inability to quickly restore growth parameters after cessation of exposure to stressors (which takes up to $24 \mathrm{~h}$ or more), while persisters are recultivated in vivo on solid growth media immediately after discontinuation of antibiotic exposure. In the absence of morphological differences, the timing of onset of growth after the return of normal conditions is the main pathognomonic trait that allows distinguishing VBNC from persister cells [24]. It is important to note that, after recultivation, the virulence of bacteria is also restored.

In the work of M. Ayrapetyan et al. [24], both these resistant forms on different physiological levels were combined into a "rest continuum" model based on a single molecular genetic mechanism of regulation.

The mechanism of emergence of resistant forms in bacterial cell populations is associated by the majority of authors with the stochastic variability of their properties determined by the genes, the environment, and the random noise which is inevitably present on all levels of biological organization, starting with the molecular one [29]. However, in the late 20th century, genetic loci of toxin-antitoxin systems (TAS) were identified in prokaryotes, and their major role in cellular physiology, which consists in metabolism reduction under stressful conditions, was elucidated [19, 31]. As shown below, these loci play a crucial role in the bacterial resistance formation, understanding of which requires considering the structure and function of TAS in more detail.

\section{Toxin-antitoxin system (TAS)}

Recent advances in genomic sequencing and bioinformatics of the latest generation have revealed a wide distribution of bacterial toxin-antitoxin systems (TAS), which has served as a powerful incentive to develop comprehensive studies of these unique protein structures [32]. The TAS genetic modules contain two genes encoding a stable toxin and an unstable antitoxin sensitive to degradation by cellular proteases (tabl.). 
Types of toxin-antitoxin systems (TAS)

\begin{tabular}{|c|c|c|c|}
\hline $\begin{array}{c}\text { TAS } \\
\text { types }\end{array}$ & Toxin & Antitoxin & Mechanisms of toxin neutralization \\
\hline I & Protein & Antisense RNA & Antitoxin blocks mRNA of toxin \\
II & Protein & Protein & Direct protein-protein interaction \\
III & Protein & Antisense RNA & Direct RNA-protein interaction \\
IV & Protein & Protein & Blockage of toxin's effect on cellular target \\
V & Protein & Protein & RNAasa of antitoxin degrades mRNA of toxin \\
VI & Protein & Protein & Degradation of toxin by ClpXP serine protease \\
\hline
\end{tabular}

Under normal conditions, the toxin and the antitoxin are in a bound state, forming a dense, non-toxic complex. However, in case of exposure to a stress associated with adverse environmental conditions, antitoxins are degraded with the involvement of ATP-dependent Lon protease, or serine bacterial protease systems ClpXP, ClpAP, and ClpCP. This leads to a sharp decrease in the rate of both translation and replication, as well as to the cessation of cell growth due to the cytotoxic effect of the toxin [32].

Further studies have shown that the TAS modules are also widely distributed among bacterial chromosomes also, but their function has long remained unknown [32]. As has been established, these systems take an active part in the biofilm formation and are also involved in the virulence and multiple resistance forming in pathogenic bacteria [31, 33, 34].

Depending on the type of genetic organization, the characteristics of the antitoxin, and the mechanism of its interaction with the toxin, six types of TAS modules are currently identified [35] (Table). In all the TAS types, toxins are represented by proteins, whereas antitoxins can be either a non-translated antisense RNA (types I and III) or a labile protein (types II, IV-VI) [19, $35,36]$. The best characterized are type I and type II modules.

Type I toxins are small-sized hydrophobic peptides that cause the loss of electrical membrane potential in cell and arrest bacterial growth. Antitoxin inhibits the activity of the toxin protein by binding mRNA [37] (Fig.). 


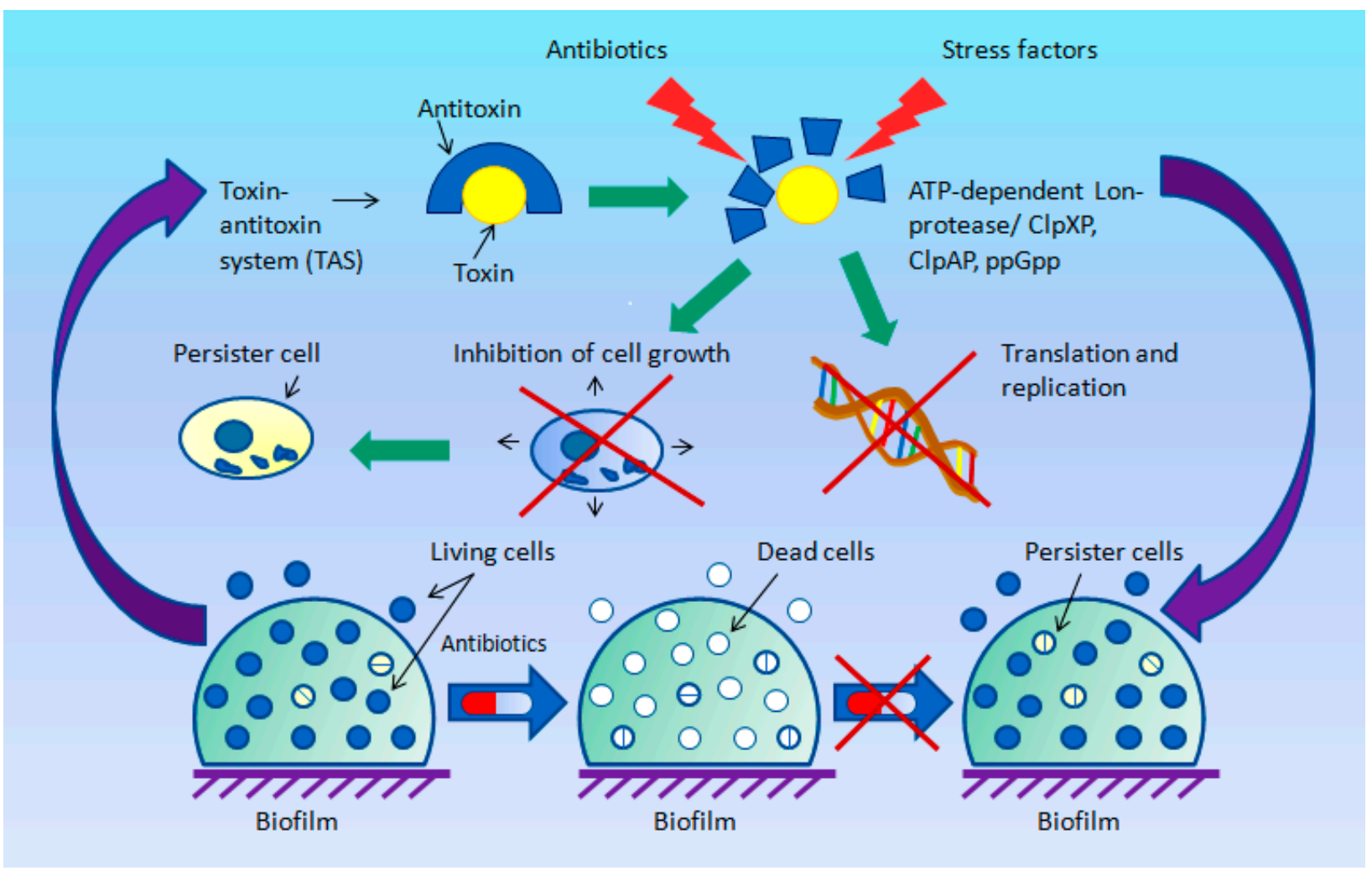

Fig. The role of toxin-antitoxin systems (TAS) in the formation of persister cells (figure by the authors).

The most wide-spread and well-studied are type II TAS modules. Toxins of this type inhibit cell replication by suppressing the activity of DNA gyrase (DNA topoisomerase II), but most of them act as translation inhibitors, exhibiting the activity of endoribonuclease (catalyze the RNA degradation) or inactivating glutamyl-tRNA synthetase (GltX) [35, 37, 38]. Antitoxins of this type, being proteins, block the toxin through direct binding [38].

The leading role of type II TAS in the formation of the persistence phenomenon is evidenced by the fact that the first discovered gene hipA of bacterial resistance was subsequently found to be responsible for coding the same-name toxin in the hipBA locus of type II TAS [39]. Moreover, the induction of overexpression of some of type II toxins-relE (genetic locus relBE) [37], mazF (locus mazEF) [37, 38], dinJ (locus dinJ-yafQ), and mqsR (locus mqsQR) [38]—was revealed in persister cells of the model wild E. coli strains.

Later studies on the same models with antibiotic therapy revealed a similar overexpression of type I TAS toxins, tisB (locus tisB-istR) and hokB (locus hokB-sokB), which was associated with high levels of guanosine pentaphosphate (ppGpp), a regulator of bacterial growth rate [40]. These toxins caused the depolarization of cell membrane and a sharp decrease in metabolic activity, as well as the induction of formation of resistant persister cells [36, 40, 41].

It has been found that the key cellular processes such as DNA replication and protein translation are inhibited in microbial cell under the effect of toxins. This inhibition leads to a 
rapid arrest of growth and a sharp decrease in metabolic activity, the formation of partial or complete resistance of bacteria to antibiotics, and make them resistant to most of antibacterial agents [41].

The study of the functions of TAS complexes has confirmed the hypothesis on physiological heterogeneity of the persister cells fraction in a population and explained the pattern of the different degrees of antibiotic resistance; moreover, it helped elucidate the mechanisms of formation of bacterial resting forms [12, 21, 22].

\section{Conclusion}

The increasing medical and epidemiological importance of sapronoses infections confirms the relevance of the study of the strategies utilized by their causative agents for maintaining the pathogenic potential, as well as the ways of their survival in natural ecosystems in the interepidemic period.

The achievements in modern cell biology have allowed a significant advance in the study of molecular genetic mechanisms of regulation of bacterial survival and maintaining their pathogenic potential in unstable conditions of natural ecosystems during the saprophytic and parasitic phases of their existence.

The dormant forms of bacterial cell existence - viable but nonculturable, L-forms, persistence, and the recently discovered contact-dependent growth inhibition (CDI) [42] determine the diversity of microbial adaptation strategies and the range of complex molecular genetic regulatory mechanisms. At the same time, resistant forms of bacteria can pose a serious threat to epidemiological safety associated with the over-estimation of disinfection completeness. Under favorable conditions, the dormant forms of bacteria are able to re-enter the active vegetative state and give rise to a new population $[8,17,43]$.

Identifying the leading role of TAS in the resistant cell form formation and the development of antibiotic resistance of bacteria is not only of fundamental importance, but also opens up broad prospects for invention of new antimicrobial technologies. The high rate of acquisition of multidrug resistance by pathogenic bacteria is an evidence of the urgency and relevance of this research trend.

Taking into account the lack of TAS genetic modules in mammals, including humans, new technological strategies can be aimed at invention of effective and highly specific biochemical modulators of toxin-antitoxin interactions. However, one of the possible disadvantages of the effectiveness of these antimicrobial strategies is the high distribution of TAS in the genome of normal microbiota in the human organism existing in symbiosis with it, which requires creating the medicinal agents targeted at several systems, including those exhibiting a probiotic action.

Another feature of this therapeutic strategy is that it is not enough just to inhibit antitoxins 
to activate toxins, as the action of the latter would require to be blocked with other drugs [43, 44]. However, encouragement of further basic research on TAS in pathogenic bacteria can provide valuable information for the invention of future antibacterial alternatives.

A number of promising antibacterial strategies are associated with ATP-dependent caseinlytic protease ClpP, an essential component of ClpXP and ClpAP complexes in bacteria [45. 46]. One of these strategies involves activation of ClpP by cyclic acyldepsipeptide (ADEP-4, one of the six configurations of this natural antibiotic) and causes uncontrolled protein degradation, inhibition of bacterial cell division, and subsequent mortality of both actively dividing and persister cells of Gram-positive flora. The effectiveness of ADEP-4 increases in combination with various antibiotics such as ciprofloxacin, linezolid, vancomycin, or rifampicin [45, 46]. Other researchers propose different ways associated with the inactivation of ClpP [46, 47]. These strategies are promising for the development of new forms of drugs based on them.

Other microbiological biotechnological approaches to control resistant cell forms are associated with the "persister awakening" mechanisms [25, 45, 48]. These approaches use compounds that do not require active transport to enter the cell, and the process of killing target cells does not need any cellular mechanisms either. Examples of such biotechnologies, active in case of combined infections associated with E. coli, S. aureus, and P. aeruginosa, are the use of DNA interstrand cross-linking antitumor cytostatic agents, mitomycin C [49] and cisplatin [50].

Thus, the study of mechanisms and patterns of regulation of the resistant cell forms formation in order to prevent their persistence and/or the identification of factors that modulate the rate of cell reversion from the vegetative active state to nonculturable cell forms provide the opportunity for improving the effectiveness of antibiotic therapy and finding the molecular targets to create new antibacterial drugs and strategies.

Conflict of interests. The authors are declare that they have no conflict of interest.

Funding. The study was supported by the Far Eastern Branch, Russian Academy of Sciences, within the framework of the "Far East" Integrated Program for Basic Research, project no. 18-5-099. The funders had no role in study design, data collection and analysis, decision to publish, or preparation of the manuscript.

Author Contributions: Conceptualization: B.A., L.S., and N.T.; Methodology: B.A.; Validation: B.A, N.F., and I.L..; Writing-Original Draft Preparation: M.B. and I.L.; Editing: B.A. and N.F.; Supervision: B.A. and L.M.;

Acknowledgments: The authors are thanks prof. N. Besednova for technical assistance and prof. T. Zaporoghets and prof. F. Shubin for comments and suggestions. 


\section{References}

1. Chen, S.; Thompson, K.M.; Francis, M.S. Environmental Regulation of Yersinia Pathophysiology. Front Cell Infect Microbiol. 2016, 6, 25. [CrossRef] [PubMed]

2. Dynamical Systems and Their Applications in Biology / Eds. S. Ruan, G.S.K. Wolkovicz, J. Wu. USA: Providence, Rhode Island, 2001. [CrossRef] [PubMed]

3. Hubálek, Z.; Rudolf, I. Microbial Zoonoses and Sapronoses. - Springer Science \& Business Media B.V. 2011. p. 456. [CrossRef] [PubMed]

4. Kuris, A.M.; Lafferty, K.D.; Sokolow, S.H. Sapronoses: a distinctive type of infectious agent. Trends Parasitol. 2014, 30(8), 386-393. [CrossRef] [PubMed]

5. Prosser, J.I.; Bohannan, B.J.M.; Curtis, T.P. The role of ecological theory in microbial ecology. Nature Reviews Microbiology, 2007, 5, 384-392. [CrossRef] [PubMed]

6. Adgamov, R.R.; Timchenko, N.F.; Zaitseva, E.A. Ecological and genetic mechanisms of development of epidemiologically significant strains of sapronoses causative agents. Biol Bull Rev. 2013, 3 (2), 125-138. [CrossRef] [PubMed]

7. Van der Does, H.C.; Rep, M. Virulence genes and the evolution of host specificity in plant-pathogenic fungi. Mol Plant Microbe Interact. 2007, 20(10), 1175-1182. [CrossRef]

8. Mecsas J.; Raupach B.; Falkow S. The Yersinia Yops inhibit invasion of Listeria, Shigella and Edwardsiella but not Salmonella into epithelial cells. Mol Microbiol. 1998, 28(6), 1269-1281. [CrossRef] [PubMed]

9. Anisimov, A.P.; Lindler, L.E.; Pier, G.B. Intraspecific diversity of Yersinia pestis. Clin Microbiol Rev. 2004, 17(2), 434-464. [CrossRef] [PubMed]

10. Lennon, J.T.; Jones, S.E. Microbial seed banks: the ecological and evolutionary implications of dormancy. Nat Rev Microbiol. 2011, 9, 119-130. [CrossRef]

11. Li, L.; Mendis, N.; Trigui, H.; Oliver, J.D.; Faucher, S.P. The importance of the viable but nonculturable state in human bacterial pathogens. Front Microbiol. 2014, 5, 258. [CrossRef]

12. Balaban, N.Q.; Merrin J.; Chait R.; Kowalik L.; Leibler S. Bacterial persistence as a phenotypic switch. Science. 2004, 305, 1622-1625. [CrossRef] [PubMed]

13. Fisher, R.A.; Gollan, B.; Helaine, S. Persistent bacterial infections and persister cells. Nat Rev Microbiol. 2017, 15(8), 453-464. [CrossRef] [PubMed]

14. Maisonneuve, E.; Castro-Camargo, M.; Gerdes K. (p)ppGpp controls bacterial persistence by stochastic induction of toxin-antitoxin activity. Cell. 2013, 154, 1140-1150. [CrossRef]

15. Maisonneuve, E.; Shakespeare, L.J.; Girke, M.; Gerdes, K. Bacterial persistence by RNA endonucleases. Proc. Natl. Acad. Sci. 2011, 108, 13206-13211. [CrossRef]

16. Maisonneuve, E.; Gerdes, K. Molecular mechanisms underlying bacterial persisters. Cell. 2014, 157, 539-548. [CrossRef] [PubMed]

17. Oliver, J.D. The viable but nonculturable state in bacteria. J Microbiol. 2005. 43, 93-100.

18. Oliver, J.D. Recent findings on the viable but nonculturable state in pathogenic bacteria. FEMS Microbiol Rev. 2010, 34, 415-425. [CrossRef] [PubMed]

19. Faruque, S.M.; Biswas, K.; Udden, S.M.; Ahmad, Q.S.; Sack, D.A.; Nair, G.B.; Mekalanos, J.J. Transmissibility of cholera: in vivo-formed biofilms and their relationship to infectivity and persistence in the environment. Proc Natl Acad Sci USA. 2006, 103, 6350-6355.

20. Nelson, E.J.; Chowdhury, A.; Flynn, J.; Schild, S.; Bourassa, L.; Shao, Y.; LaRocque, R.C.; Calderwood, S.B.; Qadri, F.; Camilli, A. Transmission of Vibrio cholerae is antagonized by lytic phage and entry into the aquatic environment. PLoS Pathog. 2008, 4, e1000187. 
21. Potgieter, M.; Bester, J.; Kell, D.B.; Pretorius, E. The dormant blood microbiome in chronic, inflammatory diseases. FEMS Microbiol Rev. 2015, 39, 567-591. [CrossRef]

22. Chaveerach, P.; ter Huurne, A. A.; Lipman, L.J.; van Knapen, F. Survival and resuscitation of ten strains of Campylobacter jejuni and Campylobacter coli under acid conditions. Appl Environ Microbiol, 2003, 69, 711-714. [CrossRef] [PubMed]

23. Day, A.P.; Oliver, J.D. Changes in membrane fatty acid composition during entry of Vibrio vulnificus into the viable but nonculturable state. J Microbiol. 2004, 42, 69-73.

24. Xiao, X.L.; Tian, C.; Yu, Y.G.; Wu, H. Detection of viable but nonculturable Escherichia coli $\mathrm{O} 157: \mathrm{H} 7$ using propidium monoazide treatments and qPCR. Can J Microbiol. 2013, 59, 157-163. [CrossRef] [PubMed]

25. Nowakowska, J.; Oliver, J.D. Resistance to environmental stresses by Vibrio vulnificus in the viable but nonculturable state. FEMS Microbiol Ecol. 2013, 84, 213-222. [CrossRef]

26. Baffone, W.; Citterio, B.; Vittoria, E.; Casaroli, A.; Campana, R.; Falzano, L.; Donelli, G.; Retention of virulence in viable but nonculturable halophilic Vibrio spp. Int J Food Microbiol. 2003, 89, 31-39. [CrossRef] [PubMed]

27. Rivers B, Steck TR. Viable but nonculturable uropathogenic bacteria are present in the mouse urinary tract following urinary tract infection and antibiotic therapy. Urol Res. 2001, 29, 60-66. [CrossRef] [PubMed]

28. Lleo, M.M.; Ghidini, V.; Tafi, M.C.; Castellani, F.; Trento, I.; Boaretti, M. Detecting the presence of bacterial DNA by PCR can be useful in diagnosing culture-negative cases of infection, especially in patients with suspected infection and antibiotic therapy. FEMS Microbiol Lett. 2014, 354, 153-160. [CrossRef] [PubMed]

29. Ayrapetyan, M., Williams, T.C., Oliver, J.D. Interspecific quorum sensing mediates the resuscitation of viable but nonculturable vibrios. Appl Environ Microbiol. 2014, 80, 2478 2483. [CrossRef] [PubMed]

30. Ayrapetyan. M., Williams. T.C., Baxter. R., Oliver. J.D. Viable but Nonculturable and Persister Cells Coexist Stochastically and Are Induced by Human Serum. Infect Immun. 2015, 83(11), 4194-4203. [CrossRef] [PubMed]

31. Ayrapetyan M, Williams TC, Oliver JD. Bridging the gap between viable but nonculturable and antibiotic persistent bacteria. Trends Microbiol 2015; 23:7-13. [CrossRef]

32. Belov A.B., Kuzin, A.A. Sapronous infections associated with the provision of medical care: problematic issues in the theory of epidemiology. Perm Medical Journal, 2017; 4 (34); 94-102. [CrossRef]

33. Belov A. B., Kulikalova, E.S. Sapronoses: ecology of pathogens, epidemiology and systematics. Epidemiology and Vaccine Prevention. 2016; 86 (1): 5-16. [CrossRef]

34. Brusinkina E. Epidemiology of infections associated with the provision of medical care caused by pathogens of the group of sapronoses. Epidemiology and Vaccine Prevention 2015; 81 (2): 50-56. [CrossRef]

35. Wood T.K. Combatting bacterial persister cells. Biotechnol Bioeng. 2016; 113(3):476-83.

36. Pienaar J.A., Singh A., Barnard T.G. The viable but nonculturable state in pathogenic Escherichia coli: A general review. Afr J Lab Med. 2016; 5(1):368. [CrossRef]

37. Hobby G.L., Meyer K., Chaffee E. Observations on the mechanism of action of penicillin. Proc Soc Exp Biol NY 1942; 50: 281-285. [CrossRef] [PubMed]

38. Ogura T., Hiraga S. Mini-F plasmid genes that couples host cell division to plasmid proliferation. Proc Natl Acad Sci USA 1983; 80: 4784-4788. [CrossRef]

39. Hayes F. Toxins-antitoxins: Plasmid maintenance, programmed cell death, and cell cycle arrest. Science 2003; 301: 1496-1499. [CrossRef] [PubMed] 
40. Uncultivated Microorganisms: Ed. Slava S. Epstein. USA, Springer, 2009. [CrossRef]

41. Michiels J.E., Van den Bergh B., Verstraeten N., Michiels J. Molecular mechanisms and clinical implications of bacterial persistence. Drug Resistance Updates. 2016; 4 (148): 1-6.

42. Korch S.B., Hill T.M., Ectopic overexpression of wild-type and mutant hipA genes in Escherichia coli: effects on macromolecular synthesis and persister formation. $J$. Bacteriol. 2006; 188: 3826-3836. [CrossRef] [PubMed]

43. Brown B.L., Grigoriu S., Kim Y., Arruda J.M., Davenport A., Wood T.K., Peti W., Page R. Three Dimensional Structure of the MqsR:MqsA Complex: A Novel TA Pair Comprised of a Toxin Homologous to RelE and an Antitoxin with Unique Properties. PLoS Pathog, 2009; 5(12): e1000706. [CrossRef] [PubMed]

44. Kim J.-S., Chowdhury N., Yamasaki R., Wood T.K. Viable But Nonculturable and Persistence Describe the Same Bacterial Stress State. Environ Microbiol. 2018;

45. Page R., Peti W. Toxin-antitoxin systems in bacterial growth arrest and persistence. Nat Chem Biol. 2016;12(4):208-214. [CrossRef] [PubMed]

46. Christensen, S.K., Maenhaut-Michel, G., Mine, N., Gottesman, S., Gerdes, K. Overproduction of the Lon protease triggers inhibition of translation in Escherichia coli: involvement of the yefM-yoeB toxin-antitoxin system. Mol Microbiol. 2004, 51, 1705-1717.

47. Bamford, R.A.; Smith, A.; Metz, J.; Glover, G.; Titball, R.W., Pagliara, S. Investigating the physiology of viable but nonculturable bacteria by microfluidics and time-lapse microscopy. BMC Biol. 2017, 15(1), 121. [CrossRef] [PubMed]

48. Van Melderen, L., Saavedra de Bast, M. Bacterial toxin-antitoxin systems: More than selfish entities? PLoS Genet, 2009; 5: 3: e1000437. [CrossRef] [PubMed]

49. Black, D.S.; Kelly, A.J.; Mardis, M.J.; Moyed, H.S., Structure and organization of hip, an operon that affects lethality due to inhibition of peptidoglycan or DNA synthesis. J. Bacteriol. 1991, 173, 5732-5739. [CrossRef] [PubMed]

50. Van Melderen, L., Toxin-antitoxin Systems: why so many, what for? Curr. Opin. Microbiol. 2010, 13, 781-785. [CrossRef] [PubMed]

51. Aizenman, E.; Engelberg-Kulka, H.; Glaser, G. An Escherichia coli chromosomal "addiction module" regulated by guanosine 30,50-bispyrophosphate: a model for programmed bacterial cell death. Proc Natl Acad Sci USA 1996; 93: 6059-6063. [CrossRef]

52. Verstraeten, N.; Knapen, W.; Fauvart, M.; Michiels J. Membrane depolarization-triggered responsive diversifikation leads to antibiotic tolerance. Microb. Cell, 2015, 2, 299-301.

53. Moyed, H.S.; Bertrand, K.P. HipA, a newly recognized gene of Escherichia coli K-12 that affects frequency of persistence after inhibition of murein synthesis. $J$ Bacteriol. 1983, 155, 768-775. [CrossRef] [PubMed]

54. Wen, Y.; Behiels, E.; Devreese, B. Toxin-antitoxin systems: their role in persistence, biofilm formation, and pathogenicity. Pathog. Dis. 2014; 70: 240-249. [CrossRef]

55. Van den Bergh, B.; Michiels, J.E.; Fauvart, M.; Michiels, J. Should we develop screens for multidrug tolerance? Expert Rev. Anti. Infect. Ther. 2016; 14(7): 613-616. [CrossRef]

56. Patra, P.; Klumpp, S. Population Dynamics of Bacterial Persistence. PLoS One. 2013, 8(5), e62814. [CrossRef] [PubMed]

57. Orman, M.A.; Brynildsen, M.P. Inhibition of stationary phase respiration impairs persister formation in E. coli. Nat. Commun. 2016, 7, 10756. [CrossRef] [PubMed]

58. Xu, H.; Roberts, N.; Singleton, F.L.; Attwell, R.W.; Grimes, D.J.; Colwell, R.R. Survival and viability of nonculturable Escherichia coli and Vibrio cholerae in the estuarine and marine environment. Microb. Ecol. 1982, 8, 313-323. [CrossRef] 
59. Thakur, Z.; Dharra, R.; Saini, V.; Kumar, A.; Mehta, P.K. Insights from the proteinprotein interaction network analysis of Mycobacterium tuberculosis toxin-antitoxin systems. Bioinformation. 2017, 13(11), 380-387. [CrossRef] [PubMed]

60. Nguyen, D.; Joshi-Datar, A.; Lepine, F.; Bauerle, E.; Olakanmi, O.; Beer, K.; McKay, G.; Siehnel, R.; Schafhauser, J.; Wang, Y.; Britigan, B.E.; Singh, P.K. Active starvation responses mediate antibiotic tolerance in biofilms and nutrient-limited bacteria. Science. 2011, 334(6058), 982-986. [CrossRef] [PubMed]

61. Wang, X.; Wood, T.K. Toxin-antitoxin systems influence biofilm and persister cell formation and the general stress response. Appl. Environ. Microbiol. 2011, 77, 55775583.

62. Lewis, K. Persister cells. Annu. Rev. Microbiol. 2010, 64, 357-372. [CrossRef]

63. Levin, B.R.; Concepción-Acevedo, J.; Udekwu, K.I. Persistence: a copacetic and parsimonious hypothesis for the existence of non-inherited resistance to antibiotics. Curr. Opin. Microbiol. 2014, 21, 18-21. [CrossRef] [PubMed]

64. Ghafourian S., Raftari M., Sadeghifard N., Sekawi Z. Toxin-antitoxin Systems: Classification, Biological Function and Application in Biotechnology. Curr Issues Mol Biol. 2014; 16:914. [CrossRef] [PubMed]

65. Hayes F., Kędzierska B. Regulating toxin-antitoxin expression: controlled detonation of intracellular molecular timebombs. Toxins (Basel). 2014; 6(1):337-358. [CrossRef]

66. Kint C.I., Verstraeten N., Fauvart M., Michiels J. New-found fundamentals of bacterial persistence. Trends Microbiol. 2012; 20: 1-9. [CrossRef] [PubMed]

67. Dhar N., McKinney J.D. Microbial phenotypic heterogeneity and antibiotic tolerance. Curr. Opin. Microbiol. 2007; 10: 30-38. [CrossRef] [PubMed]

68. Barth, V.C.; Rodrigues, B.Á.; Bonatto, G.D.; Gallo, S.W.; Pagnussatti, V.E.; Ferreira, C.A.S.; de Oliveira, S.D. Heterogeneous persister cells formation in Acinetobacter baumannii. PLoS One, 2013, 8(12), e84361. [CrossRef] [PubMed]

69. Allison, K.R.; Brynildsen, M.P.; Collins, J.J. Metabolite-enabled eradication of bacterial persisters by aminoglycosides. Nature. 2011, 473, 216-220. [CrossRef]

70. Amato, S.M.; Brynildsen, M.P. Persister heterogeneity arising from a single metabolic stress. Curr. Biol. 2015, 25, 2090-2098. [CrossRef] [PubMed]

71. Maleki, A.; Ghafourian, S.; Pakzad, I.; Badakhsh, B.; Sadeghifard, N. mazE antitoxin of toxin antitoxin system and fbpA as reliable targets to eradication of Neisseria meningitidis. Curr Pharm Des. 2017. [CrossRef] [PubMed]

72. Jaén-Luchoro, D.; Aliaga-Lozano, F.; Gomila, R.M.; Gomila, M.; Salvà-Serra, F.; Lalucat, J.; Bennasar-Figueras, A. First insights into a type II toxin-antitoxin system from the clinical isolate Mycobacterium sp. MHSD3, similar to epsilon/zeta systems. PLoS One. 2017, 12(12), e0189459. [CrossRef] [PubMed]

73. Brown, B.L.; Grigoriu, S.; Kim, Y.; Arruda, J.M.; Davenport, A.; Wood, T.K.; Peti, W.; Page, R. Three dimensional structure of the MqsR:MqsA complex: a novel TA pair comprised of a toxinhomologous to RelE and an antitoxin with unique properties. PLoS Pathog. 2009, 5(12), e1000706. [CrossRef] [PubMed]

74. Shah, D.; Zhang, Z.; Khodursky, A.; Kaldalu, N.; Kurg, K.; Lewis, K. Persisters: a distinct physiological state of E. coli. BMC Microbiol. 2006; 6: 53. [CrossRef] [PubMed]

75. Keren, I.; Shah, D.; Spoering, A.L.; Kaldalu, N.; Lewis, K. Specialized persister cells and the mechanism of multidrug tolerance in Escherichia coli. J. Bacteriol. 2004, 186, 81728180. [CrossRef] [PubMed]

76. Dörr, T.; Vulić, M.; Lewis, K. Ciprofloxacin causes persister formation by inducing the TisB toxin in Escherichia coli. PLoS Biol. 2010, 8, e1000317. [CrossRef] 
77. Lewis, K.; Shan, Y. Persister Awakening. Mol Cell. 2016, 63(1), 3-4. [CrossRef]

78. Lewis, K. Platforms for antibiotic discovery. Nat Rev Drug Discov. 2013, 12(5), 371-387.

79. Moussa, T.A.A.; Kadasa, N.M.S.; Al Zahrani, H.S.; Ahmed, S.A.; Feng, P.; Gerrits van den Ende, A.H.G.; Zhang, Y.; Kano, R.; Li, F.; Li, S.; Song, Y.; Dong, B.; Rossato, L.; Dolatabadi, S.; Hoog, S. Origin and distribution of Sporothrix globosa causing sapronoses in Asia. J Med Microbiol. 2017, 66(5), 560-569. [CrossRef] [PubMed]

80. Zeiler, E.; List, A.; Alte, F.; Gersch, M.; Wachtel, R.; Poreba, M.; Drag, M.; Groll, M.; Siebera, S.A. Structural and functional insights into caseinolytic proteases reveal an unprecedented regulation principle of their catalytic triad. Proc Natl Acad Sci USA. 2013, 110(28), 11302-11307. [CrossRef] [PubMed]

81. Wood, TK. Strategies for combating persister cell and biofilm infections. Microb Biotechnol. 2017, 10(5), 1054-1056. [CrossRef] [PubMed]

82. Kwan, B.W.; Chowdhury, N.; Wood, T.K. Combatting bacterial infections by killing persister cells with mitomycin C. Environ Microbiol. 2015, 17, 4406-4414. [CrossRef]

83. Chowdhury, N.; Wood, T.L.; Martínez-Vázquez, M.; García-Contreras, R.; Wood, T.K. DNA-crosslinker cisplatin eradicates bacterial persister cells. Biotechnol Bioeng. 2016, 113, 1984-1992. [CrossRef] [PubMed]

84. Ruhe Z.C.; Low D.A.; Hayes C.S. Bacterial contact-dependent growth inhibition (CDI). Trends Microbiol. 2013, 21(5), 230-237. [CrossRef] [PubMed]

85. Hall, A.M.; Gollan, B.; Helaine, S. Toxin-antitoxin systems: reversible toxicity. Curr Opin Microbiol. 2017, 36, 102-110. [CrossRef] [PubMed]

86. Yang Q.E.; Walsh T.R. Toxin-antitoxin systems and their role in disseminating and maintaining antimicrobial resistance. FEMS Microbiol Rev. 2017, 41(3), 343-353.

87. Ronneau S.; Helaine S. Clarifying the Link between Toxin-Antitoxin Modules and Bacterial Persistence. J Mol Biol. 2019, pii: S0022-2836(19)30150-0. [CrossRef] 